\title{
Gambaran Penyakit Ginjal Kronik dan Komplikasinya di RSUD Koja Periode Juli-November 2017
}

\author{
Suzanna Ndraha ${ }^{1}$, Jean Nadya PR ${ }^{2}$, Marshell Tendean ${ }^{2}$, Mardi Santoso ${ }^{2}$ \\ ${ }^{1}$ SMF Penyakit Dalam RSUD Koja dan Staf Pengajar Bagian Ilmu Penyakit Dalam, \\ Fakultas Kedokteran Universitas Krida Wacana \\ ${ }^{2}$ Staf Pengajar Bagian Ilmu Penyakit Dalam, Fakultas Kedokteran Universitas Krida Wacana \\ Alamat korespondensi: susanndraha@gmail.com
}

\begin{abstract}
Abstrak
Penyakit ginjal kronik (PGK) adalah suatu proses patofisiologi dengan etiologi yang beragam, mengakibatkan penurunan fungsi ginjal yang progresif, dan pada umumnya berakhir dengan gagal ginjal. Penyakit ginjal kronik merupakan masalah kesehatan masyarakat di seluruh dunia termasuk di Indonesia. Tujuan penelitian ini adalah diketahuinya proporsi dan jenis komplikasi pasien PGK di Penyakit Dalam RSUD Koja. Penelitian ini bersifat observasional, dengan mengambil sampel secara consecutive sampling pada unit rawat jalan dan rawat inap Penyakit Dalam RSUD Koja selama Juli November 2017. Didapatkan 261 subyek, 149 (57,09\%) laki-laki dan 112 (42,91\%) perempuan, dengan rentang usia antara 18-72 tahun, dengan jumlah terbanyak pada kelompok usia 45-65 tahun (62,45\%),stadium PGK terbanyak adalah stadium V (62,.07\%), sebanyak 74,33\% memiliki komplikasi, terbanyak adalah ensefalopati uremik $94,64 \%$, anemia $88,7 \%$ dan volume overload $88,1 \%$. Di bagian rawat jalan dan Rawat Inap Penyakit Dalam RSUD Koja periode Juli-November 2017 sebanyak 74,33\% dari pasien PGK memiliki komplikasi, komplikasi terbanyak adalah ensefalopati uremik $(94,64 \%)$ diikuti oleh anemia $88,7 \%$ dan volume overload $88,1 \%$.
\end{abstract}

Kata Kunci : komplikasi, penyakit ginjal kronik, ensefalopati uremik

\section{Renal Failure Complications at Koja District Hospital In the Period of July-November 2017}

\begin{abstract}
Chronic Kidney Disease (CKD) is a pathophysiological process due to various etiologies, characterized by progressive decrease in kidney function which can lead to end stage renal disease. $C K D$ is a global public health problem, including in Indonesia. The aim of this research was to find out the proportion and types of complications among patients at Koja Hospital. Data were obtained based on an observational study of the medical records of out-and in-patients at the Internal Medicine Department of Koja Hospital. Consecutive sampling was done from July-November 2017. Among 261 subjects, 149 (57.09\%) were male and 112 (42.91\%) were female, with age ranging from 18 to 72 years old. The most frequent age was $45-65$ years $(62.45 \%)$. Around $62.07 \%$ of all the patients suffered from CKD stage 5. Of all the subjects studied, $74.33 \%$ had complications. The most common complication was uremic encephalopathy (94.64\%), followed by anemia (88.7\%) and volume overload (88.1\%). The study concludes that uremic encephalopathy, anemia, and volume overload were the most common complications among CKD patients at Koja Hospital during the period of study.
\end{abstract}

Keywords: complications, Chronic Kidney Disease, uremic encephalopathy 


\section{Pendahuluan}

Penyakit ginjal kronik (PGK) adalah suatu proses patofisiologi dengan etiologi yang beragam, mengakibatkan penurunan fungsi ginjal yang progresif, dan pada umumnya berakhir dengan gagal ginjal. Selanjutnya, gagal ginjal adalah suatu keadaan klinis yang ditandai dengan penurunan fungsi ginjal yang ireversibel, pada suatu derajat yang memerlukan terapi pengganti ginjal yang tetap, berupa dialisis atau transplantasi ginjal. ${ }^{1}$ PGK merupakan masalah kesehatan masyarakat di seluruh dunia. ${ }^{1}$ Di Indonesia, berdasarkan Pusat Data dan Informasi Perhimpunan Rumah Sakit Seluruh Indonesia, jumlah pasien gagal ginjal kronik diperkirakan sekitar 50 orang per satu juta penduduk, $60 \%$ diantaranya adalah laki-laki, usia dewasa, dan usia lanjut. ${ }^{2}$ Di Malaysia, dengan populasi 18 juta, diperkirakan terdapat 1.800 kasus baru gagal ginjal pertahunnya. Di negara-negara berkembang lainnya, insiden ini diperkirakan sekita 40-60 kasus per juta penduduk pertahun. ${ }^{2}$ Sebuah studi yang dilakukan Perhimpunan Nefrologi Indonesia melaporkan sebanyak $12,5 \%$ populasi di Indonesia mengalami penurunan fungsi ginjal. ${ }^{2}$

Tujuan penelitian ini adalah untuk mengetahui proporsi penyakit ginjal kronik yang mengalami komplikasi di RSUD Koja, dan apa saja jenis komplikasi penyakit ginjal kronik yang ada di Penyakit Dalam RSUD Koja.

\section{Metoda}

Penelitian ini merupakan jenis penelitian deskriptif. Sampel diambil secara consecutive sampling dimana semua subyek yang datang dan memenuhi kriteria inklusi dimasukan ke dalam penelitian sampai kurun waktu tertentu sehingga jumlah yang dibutuhkan terpenuhi.

Penelitian ini dilaksanakan di Departemen Penyakit Dalam Rumah Sakit Umum Daerah Koja Jakarta selama bulan Juli sampai November 2017. Subjek penelitian adalah pasien Penyakit Ginjal Kronik yang datang ke Rawat Jalan dan Rawat Inap Penyakit Dalam RSUD Koja.

Data yang sudah terkumpul dicatat dan diolah secara manual. Prosedur pengolahan data yang dilakukan melalui tahap cleaning (melakukan pembersihan data), editing (menyunting data), coding (membuat lembaran kode), dan entering (memasukkan data ke dalam tabel). Peneliti menggunakan software SPSS 17.0 untuk menganalisis data yang telah dikumpulkan secara statistik deskriptif.

\section{Hasil Penelitian}

Penelitian selama bulan Juli sampai November 2017 ini mendapatkan 261 subjek, 149 (57,09\%) laki-laki dan 112 (42,91\%) perempuan, dengan rentang usia antara 18 72 tahun, dengan jumlah terbanyak pada kelompok usia 45-65 tahun (62,5\%). Kelompok PGK stadium V terbanyak $(62,07 \%)$, sebanyak $74.33 \%$ memiliki komplikasi, dan komplikasi terbanyak adalah ensefalopati uremik $(94,64 \%)$ sebagaimana dipaparkan pada Tabel 1, Gambar 1 dan Gambar 2.

\section{Pembahasan}

Pada penelitian ini didapatkan, pasien PGK di RSUD Koja didominasi oleh gender laki-laki sebesar 57,09\%. Hasil temuan ini sesuai dengan penelitian oleh Pranandari dan Supadmi yang menyatakan bahwa laki-laki mempunyai risiko lebih tinggi untuk mengalami gagal ginjal dibandingkan dengan perempuan. ${ }^{3}$ Pada sebaran kelompok umur, usia terbanyak didominasi pada kelompok 4565 tahun $(62,45 \%)$. Ini juga sesuai dengan Pranandari dan Supadmi yang mendapatkan usia 60 tahun keatas mempuyai risiko 2,2 kali lebih besar mengalami gagal ginjal kronik dibandingkan dengan pasien usia $<60$ tahun. $^{3}$ Berdasarkan jenis komplikasi, didapatkan bahwa anemia merupakan komplikasi tertinggi kedua yaitu sebesar $88,7 \%$ dari seluruh total responden. Hasil temuan ini sejalan dengan penelitian yang dilakukan oleh Hidayat dkk yang menyatakan bahwa angka kejadian anemia pada pasien penyakit ginjal kronik sebesar $88,5 \%{ }^{4}$ Hipertensi pada penelitian ini didapatkan sebesar $69 \%$, tidak bertentangan dengan Tedla dkk yang mendapatkan kejadian hipertensi sebesar $59,9 \%$ pada PGK stadium III, dan $84,1 \%$ pada PGK stadium IV-V. ${ }^{5}$ 
Tabel 1. Karakteristik Pasien Penyakit Ginjal Kronik dan Komplikasinya $(n=261)$

\begin{tabular}{lll}
\hline Karakteristik & $\begin{array}{l}\mathbf{N} \\
(\mathbf{n = 2 6 1 )}\end{array}$ & $\mathbf{( \% )}$ \\
\hline Jenis Kelamin & & \\
Laki-laki & 149 & $57,09 \%$ \\
Perempuan & 112 & $42,91 \%$ \\
Usia & & \\
$18-25$ tahun & 4 & $1,53 \%$ \\
$26-45$ tahun & 49 & $18,77 \%$ \\
$45-65$ tahun & 163 & $62,45 \%$ \\
$>65$ tahun & 45 & $17,24 \%$ \\
Rawat & & \\
Rawat Inap & 142 & $54,41 \%$ \\
Rawat Jalan & 119 & $45,59 \%$ \\
Stadium & & \\
Stadium I & & $0,00 \%$ \\
Stadium II & 2 & $0,77 \%$ \\
Stadium II & 54 & $20,69 \%$ \\
Stadium IV & 43 & $16,48 \%$ \\
Stadium V & 162 & $62,07 \%$ \\
\hline
\end{tabular}

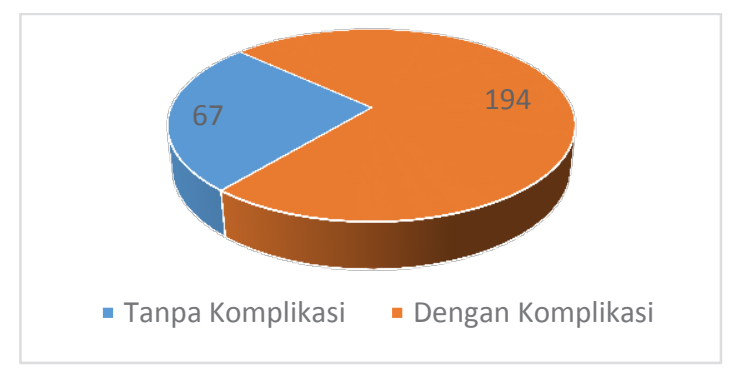

Gambar 1. Distribusi PGK Tanpa

Komplikasi (67; 25,67\%)

vs dengan Komplikasi (194; 74,33\%)

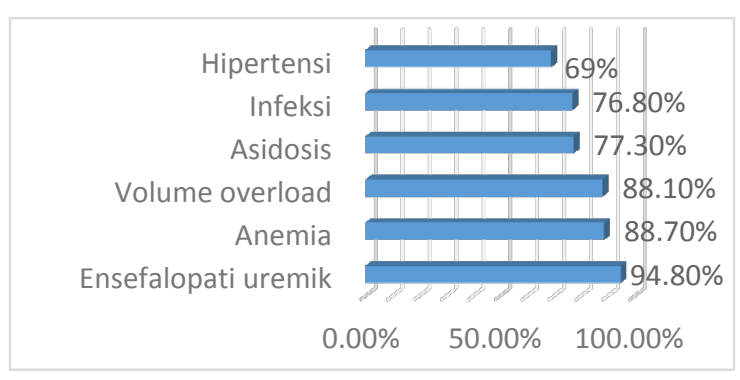

Gambar 2. Distribusi Jenis Komplikasi PGK $(n=194)$
Asidosis metabolik merupakan komplikasi keempat yaitu sebesar 77,3\%. Kraut dan Madias mengemukakan hubungan antara asidosis metabolik dan PGK, di mana pada PGK dengan GFR dibawah $25 \mathrm{~mL} / \mathrm{min} / 1,73 \mathrm{~m} 2$ mulai terjadi berkurangnya ekskresi amonium ginjal dan keseimbangan asam yang positif yang mengakibatkan penurunan konsentrasi bikarbonat serum dan asidosis metabolik. ${ }^{6}$ Ensefalopati uremik merupakan komplikasi tertinggi pertama yaitu sebesar $94,8 \%$. Temuan ini sejalan dengan penelitian yang dilakukan oleh Sirait dan Sari yang mendapatkan ensefalopati uremik pada $93,40 \%$ pasien dengan PGK.

Volume overload merupakan komplikasi tertinggi ketiga yaitu sebesar $88,1 \%$. Volume overload adalah faktor prognosis penting pada PGK, karena berhubungan dengan gangguan oksigenasi, kerusakan end-organ, perawatan lama di rumah sakit, peningkatan morbiditas dan mortalitas. Di Amerika Serikat, 38\% dari seluruh kematian pada pasien PGK yang menjalani dialisis adalah berhubungan dengan penyakit kardiovaskular seperti aritmia, cardiac arrest hipertrofi ventrikel kiri dan hipertensi. ${ }^{8}$ Dari 350.000 pasien gagal ginjal terminal, sekitar 280.000 episode akut pertahun berhubungan dengan volume overload. ${ }^{8}$

Infeksi merupakan komplikasi kedua terendah yaitu sebesar $68,97 \%$. Sebuah studi di Amerika Serikat menemukan bahwa presentase pasien penyakit ginjal kronik rawat inap yang mengalami infeksi adalah $56 \%$ pada seluruh pasien yang menerima hemodialisis dan pasien yang rutin menjalani dialisis peritoneal. ${ }^{9}$

Penelitian kami menganalisis pasien PGK pada semua stadium baik yang menjalani hemodialisis maupun tidak. Sedangkan pada penelitian Dalrymple, dianalisis secara lebih spesifik jumlah pasien gagal ginjal kronik stadium akhir atau terminal yang menjalani hemodialisis secara rutin. Baik di Indonesia maupun negara lain, data penelitian insidensi atau prevalensi kejadian infeksi pada pasien dengan gagal ginjal kronik masih terbatas. Selain itu, penelitian yang secara spesifik meneliti pasien PGK dengan komplikasi infeksi berdasarkan tingkat keparahan PGK (stadium) belum ada. ${ }^{9}$ 


\section{Simpulan}

Sebanyak 74,33\% dari pasien dengan PGK di RSUD Koja memiliki komplikasi, dan komplikasi terbanyak adalah ensefalopati uremik (94.64\%) diikuti oleh anemia 88,7\% dan volume overload $88,1 \%$. Hal ini menunjukan pentingnya deteksi dini, penanganan segera dan pencegahan komplikasi terhadap pasien PGK.

\section{Daftar Pustaka}

1. Suwitra K. Penyakit ginjal kronik. Dalam: Sudoyo AW, Setiyohadi B, Alwi I, Simadibrata M, Setiati S. Buku ajar ilmu penyakit dalam. Edisi VI. Jakarta:Interna Publishing; 2014. 1035-40

2. Arwinda P, Utami P. Identification of drug related problems in hypertension patients with chronic renal failure in the ward RS PKU Muhammadiyah Yogyakarta in the period of January 2014-May 2016. University of Muhammadiyah Yogyakarta. 2017:7:13-4

3. Pranandari, Supadmi. Faktor risiko gagal ginjal kronik di unit hemodalisis RSUD Wates Kulon Progo. Fakultas Farmasi Universitas Ahmad Dahlan. 2015;11(2): 317-19.
4. Hidayat dkk. Hubungan kejadian anemia dengan penyakit ginjal kronik pada pasien yang dirawat di Bagian Ilmu Penyakit Dalam RSUP dr M Djamil Padang. Fakultas Kedokteran Universitas Andalas Padang. Jurnal Kesehatan Andalas. 2016; 53.

5. Tedla FM, Brar A, Brown C, Browne R. Hypertension in chronic kidney disease: navigating the evidence, International Journal of Hypertension, 2011, 9 , Kraut JA, Madias NE. Metabolic acidosis of CKD: An Update. Am J Kidney Dis. 2016;67(2):30717. DOI: https://doi.org/ 10.1053/j.ajkd. 2015.08.028

6. Sirait FRH, Sari MI. Ensefalopati uremikum pada gagal ginjal kronis. Fakultas Kedokteran, Universitas Lampung. 2017;7(1):2.

7. Ekinci C, Karabork M, Siriopol D, Dincer N, Covic A, Kanbay M. Effects of volume overload and current techniques for the assessment of fluid status in patients with renal disease. Blood Purif 2018;46:34-47. DOI: $10.1159 / 000487702$.

8. Dalrymple LS, Go AS. Epidemiology of acute infections among patients with chronic kidney disease. Clin J Am Soc Nephrol. Sep 2013;3(5):20. 